\title{
A Study on the Application of the Construction of College English With Ideological and Political Education
}

\author{
Liao Qinsi ${ }^{1, *}$ Zhang $\operatorname{Dan}^{1}$
}

\author{
${ }^{1}$ Hunan University of Information and Technology \\ *Corresponding author. Email: $3283900800 @ q q . c o m$
}

\begin{abstract}
College English is a very important course for college students in their study and life. With the continuous development of socialism with Chinese characteristics, the effective integration of ideological and political education and college English curriculum has become an inevitable choice for educational development. The effective combination of the two has also become an important driving force to promote the overall quality of students and the continuous development of Chinese education. How college teachers effectively integrate English courses with ideological and political education in teaching is an important issue faced by all teachers. Based on this, this article briefly introduces the meaning and significance of the college English course with ideological and political education and illustrates some obstacles in teaching. It mainly promotes some effective strategies of combining college English with ideological and political education, aiming to improve students' growth and achievement.
\end{abstract}

Keywords: College English, ideological and political education, application strategies

\section{INTRODUCTION}

College English course contains a wide range of content. The diversity of the course content requires college students to form correct values in the learning process. It is very important for teachers and students to hold the correct values in the teaching and learning process. Only holding the correct values can help students distinguish right from wrong when learning different humanities and history knowledge[1]. Based on this, the essence of "Establishing moral integrity in cultivation" that runs through ideological and political education in College English course is a significant measure to promote students' development.

\section{THE MEANING AND APPLICATION SIGNIFICANCE OF COLLEGE ENGLISH COURSE WITH IDEOLOGICAL AND POLITICAL EDUCATION}

Ideological and political education plays an important part in promoting education reform. It adapts to social development. It is a new form of educational philosophy, the essence of which is to establish moral education, the concept of collaborative education, the structure of which is multidimensional and diversified, the method of which is a combination of explicit and implicit, and the main expression of which is to integrate ideological and political education elements such as theoretical knowledge, value concepts and spirit of ideology and politics into various courses.

The construction of college English course with ideological and political education, on the other hand, means that teachers take the standard requirements for the construction of college English course with ideological and political education as their goal, combine the goal in the class with teaching materials, form an atmosphere of good ideological and political education class and let students establish the correct values gradually but imperceptibly[2].

Building class of college English with ideological and political education is an important bridge builder between Chinese and Western cultural exchange. It can spread Chinese excellent culture. It is an important initiative to enhance China's cultural confidence[3]. The content of the college English course is rich in diversity, and students can learn about the excellent Chinese and foreign cultures and compare the differences between them by understanding the knowledge conveyed by the teaching process, but also because of the differences in these two 
languages, which sometimes causes cultural misunderstandings and, over time, may make students form a rejectionist mentality towards learning English.

\section{THE HINDERING FACTORS OF THE CONSTRUCTION OF COLLEGE ENGLISH WITH IDEOLOGICAL AND POLITICAL EDUCATION}

Building class of college English with ideological and political education needs a large number of ideological and political theories into the classroom, only in this way can have an impact on students implicitly, but currently, in English class, ideological and political theories elements are in a state of absence, which brings a certain resistance to the construction of College English with ideological and political education class[4].

\subsection{Some teachers lack ideological and political theory awareness in teaching class}

The main responsibility of teachers is to help students to grow, in short, to instruct, educate, and solve problems. However, some teachers mainly focus on imparting knowledge to students. Some of teachers lack of awareness of transmitting ideological and political education to the class directly determines the teachers' neglect of both educating and solving problems in the teaching process, and the direct result of the teachers' neglect is that the students are influenced by the teachers themselves to focus only on the degree of mastering knowledge in the learning process[5]. In the long run, the students' moral development will be limited.

\subsection{English teachers focus too much on foreign culture and ignore Chinese culture in the selection of teaching materials}

The purpose of teaching English is to enable students to master various aspects of knowledge and culture through language learning, so many teachers often choose foreign cultures when selecting teaching content. This is not conducive to the cultivation of moral values. For example, many students like to celebrate Western Valentine's Day, but ignore the traditional Chinese Qixi Festival, which directly results in students ignoring Chinese traditional culture[6].

\section{STRATEGIES FOR TEACHING COLLEGE ENGLISH WITH IDEOLOGICAL AND POLITICAL EDUCATION}

The teachers' awareness of ideological and political education is an important prerequisite for teaching in the class. Teachers should prepare an effective teaching design combining English learning with ideological and political education before the class, practice teaching procedure in the class, reflects after the class and, make some adjustments for the next class. Based on this, the following section will elaborate on the teaching strategies.

\subsection{Strengthening the ideological and political literacy of college English teachers}

The ideological and political literacy of college English teachers is an important prerequisite for effective combination of the English class and ideological and political education. Considering the current situation that among college English teachers some of them lack of ideological and political education awareness themselves, their ideological and political literacy can be improved in the following ways: firstly, the college provides corresponding training sessions and exchange meetings, and English teachers learn to understand the current form of education, the country's educational goals and ideological and political theories by enhancing their own ideological and political awareness, thus providing the prerequisites for student growth[7]. Secondly, the teachers themselves learn about current developments and the international situation through the use of apps like Xuexi app, which indirectly enhance teachers' awareness about how to combine ideological and political education with English teaching, so that they can make up-to-date college English teaching design and practice in class to promote the effective consolidation of students' moral values.

\subsection{Integrating ideological and political education into teaching objectives and teaching design}

The construction of ideological and political education in English class requires teachers to clarify the teaching objectives and make effective teaching design for the teaching contents before the class, as to make sufficient preparation for smoothing the implementation of the teaching and learning process for the class[8]. In this regard, teachers dig ideological and political education based on the content of text materials to achieve the teaching objectives. Firstly, the college can set up an ideological and political education group to sort out and identify the content that students need to learn, and to decide which teaching content that needs to be integrated by clarifying the objectives of college English course with ideological and political education. Secondly, the teacher will use the internet to integrate the teaching materials and ideological and political education resources, and combine them together, design the teaching content and process. Afterward, the teacher will discuss the teaching designs in the group, find out what can be added as ideological and political education in the teaching process and modify it in time. Finally, teachers can make use of Ted and other platforms online to explore videos, speeches and reports related to the teaching 
materials as a supplement to the class to achieve teaching objectives.

\subsection{Integrating ideological and political education into English class}

Practicing ideological and political education in College English mainly focus in English class. Doing exercises in class are an important part of the teaching process. Based on this, teachers make use of the "Practicing session" to effectively guide college students to build national self-confidence and pride in the class, forming good moral and social values, by combining ideological and political education and the exercise materials. Firstly, teachers enhance teaching material by introducing the subject as the class begins, so that students have a general understanding of it. Secondly, according to the exercises, teachers can guide students to understand the differences between Chinese and Western cultures and values in this session, and guide to treat them with a critical attitude and avoid overreaction. Finally, teachers reflect the subject after the class through a variety of summary forms such as language and video, while enhancing the fun of the whole class.

\subsection{Integrating ideological and political education into teaching evaluation and extra- curricular activities}

Teaching evaluation is an effective feedback mechanism for education. Teachers can understand the problems that arise in the teaching process through students' evaluation or feedback. Aiming at the current problems in establishing college English with ideological and political education, teachers can achieve the goal by integrating ideological and political education into the teaching evaluation and extra-curricular activities. Firstly, college can develop a corresponding evaluation system by inviting teaching experts in the field of English course with ideological and political education to observe the English class, and through the feedback of experts to keep abreast of the specific situation of college teachers in the process of teaching English with ideological and political education. Secondly, teachers can use information platforms such as to create online questionnaires on building ideological and political education into College English. Distribute questionnaires to students to know the actual effect of English course with ideological and political education construction through students' real feedback on the class. Finally, teachers can achieve the goal of integrating the construction of ideological and political education in college English course through extra-curricular extension activities, such as reading some books on Chinese culture or government work reports in Chinese and English translation.

\section{CONCLUSION}

College English is a significant course for cultivating students' comprehensive abilities and cultural literacy, as well as enhancing college students' national pride and self-confidence. It also requires that college teachers constantly adjust their pace correspondingly, thus adding impetus to the progress of education. Through constant teaching innovation, teachers will gradually achieve the goal of "establishing moral integrity in cultivation" in the construction of college English with ideological and political education.

\section{REFERENCES}

[1] J. Chen, Research on the practical system of english education and teaching in higher vocational colleges based on "curriculum ideological and political", in: International Journal of Education and Economics, vol.4, 2020.

[2] Y. Yang, D.Wang, The realization of ideological and political education in college English based on cultural confidence, in: Creative Education, vol.11, 2020.

[3] H. Huang, Exploring the higher vocational English teaching model under the curriculum ideological and political system, in: Advances in Higher Education, vol.9, 2020.

[4] J. Feng, Study on the practice of ideological and political education in college English teaching in a case of "unit 4 heroes of our time" of new horizon college English, in: Proceedings of the 4th International Conference on Scientific Technological Innovation and educational development, vol.2, 2020, pp:175-178.

[5] W. Chunyan, Reform of college English teaching from the perspective of ideological and political education, in: Lifelong Education, vol.6,2020.

[6] W. Nianying, A brief analysis of the integration of college English teaching and ideological and political education under the new situation, in: Overseas English, vol.18, 2020, pp: 277-278.

[7] G. Lili, The research and practice of integrating the "courses for ideological and political education" with public English teaching, in: International Journal of Computational and Engineering, vol.3, 2020 .

[8] L. Jingyi, Research on the integration of ideological and political education and entrepreneurship education in colleges and universities, in: Proceedings of 2019 5th International Workshop on Education, Development and Social Sciences, 2019, pp: 123-127. 